\title{
Jeremiah 32:17-18a: The Great and Powerful God Shows Steadfast Love to Thousands, but Punishes Sin
}

\author{
Marius D. Terblanche (University OF THE FreE State)
}

\begin{abstract}
The author of Jeremiah's prayer (Jer 32:16-25) used fixed expressions from various texts. In 32:17-18a he applied material borrowed from Jer 27:5 and Deut 5:9-10; 7:10 to portray YHWH as the great and powerful God, who shows steadfast love to thousands, but punishes sin. I will argue that this portrayal of YHWH became the guiding theme in Jeremiah's prayer (32:16-25) and YHWH reply to the prayer (32:26-44). In the prayer, set at a time when Judah was experiencing the power of the Babylonians, YHWH's incomparable power and his disposition to intercede testify to the fact that the prophet expected him to intervene. From YHWH's reply to the prayer (32:26-44) it is evident that it was his incomparable power that would enable the exiles to return and to start a new life in Benjamin and Judah. The motivation for restoring his people lies solely within the realm of the initiative of the God who shows steadfast love to thousands.
\end{abstract}

KEYWORDS: Jeremiah's prayer; Jer 32:16-44; Deut 5:9-10; 7:10; the grace formula

\section{A INTRODUCTION}

Jeremiah $32: 16-23^{*}$ has been depicted as a mosaic constructed from fixed expressions borrowed from other texts. ${ }^{1}$ The similarities in vocabulary between Deut 26:1-15 and Jer 32:16-23* are the most apparent. ${ }^{2}$ Jeremiah 32:16-23* also features material occurring elsewhere in the book of Jeremiah. In the

* Article submitted: 31/10/2016; peer-reviewed: 13/01/2017; accepted: 2/02/2017. To cite: Marius D. Terblanche, "Jeremiah 32:17-18a: The Great and Powerful God Shows Steadfast Love to Thousands, but Punishes Sin," Old Testament Essays 30/1 (2017: 151-164. Doi: http://dx.doi.org/10.17159/2312-3621/2017/v30n1a9

1 Cf. Gunther Wanke, "Jeremias Gebet nach dem Ackerkauf (Jer 32,16-25) und die Pentaeuch: Eine Problemanzeige," in Auf dem Weg zur Endgestalt vom Genesis bis II Regum: Festschrift Hans-Christoph Schmitt zum 65. Geburtstag, ed. Martin Beck and Ulrike Schorn, BZAW 370 (Berlin: De Gruyter, 2006), 277.

2 Cf. Wanke, "Jeremias Gebet," 277; Georg Fischer, "Gebete als hermeneutischer Schlüssel zu biblischen Büchern - am Beispiel Jeremia," in Congress Volume: Ljubljana 2007, ed. André Lemaire, VTSup 133 (Leiden: Brill, 2010), 232; Nathan Mastnjak, Deuteronomy and the Emergence of Textual Authority in Jeremiah, FAT 2/87 (Tübingen: Mohr Siebeck, 2016), 157. 
affirmation of YHWH's power in creation in v. 17 the author is evidently dependent on the depiction of YHWH as the creator of the earth in 27:5. ${ }^{3}$ In Jer 32:18a YHWH is characterised as the one who is merciful, but punishes sin. When Israel was testifying about YHWH's mercy, they generally did not say anything about his power. ${ }^{4}$ However, in Jer 32:17-18a the reference to YHWH's gracious character is linked to that of his incomparable power as is expressed by his acts as creator. The verb עשהה occurs in v. 17 as well as 18a. While describes YHWH's acts as creator in v. 17, in the subsequent verse it is utilised to reveal that YHWH's חסד is constantly available to thousands. ${ }^{5}$ Since the verbs in v. 18a are pointed as participles, the clauses עשה חסד לאלפים and ומשלם עון אבות אל־חיק בניהה אחריהם are obviously subordinate to the final clause in v. 17. Fretheim has suggested that the testimony to YHWH's power in Jer 32:17 grounds all that follows as is demonstrated by the immediate placement of the word about nothing being too difficult for YHWH. ${ }^{6}$ The present article sets out to show that the guiding theme to Jeremiah's prayer (32:16-25) and YHWH's reply to the prayer $(32: 26-44)$ is to be found in the testimony to YHWH's power as well as the characterisation of him as the one that shows mercy, but punishes sin.

Carr has made a persuasive case for the use of terms such as "influence" or "allusion" rather than the term "intertextuality" for binary, reconstructable relationships between biblical texts. ${ }^{7}$ As Carr acknowledges, this was already suggested by Sommer and others. ${ }^{8}$ According to Sommer an allusion does not only consist in the echoing of an earlier text, but also in the utilisation of the marked material for some rhetorical or strategic end. Some elements of the source text help to construct a reading of the alluding text. ${ }^{9}$ Schultz asserts that a quotation does not only recall the quoted words, but also the context of their

3 Cf. Leslie C. Allen, Jeremiah: A Commentary, OTL (Louisville: Westminster John Knox, 2008), 368; Marius D. Terblanche, "Yahweh is the Creator of (Heaven and) Earth: The Significance of the Intertextual Link between Jeremiah 27:5 and 32:17," OTE 27 (2014): 639-640. The use of the phrase בכח הגדול ובזרע הנטוה with reference to YHWH's freedom to act as creator is unique to Jer 27:5 and 32:17. In Deut 9:29 and Kgs 17:36 the phrase refers to the Exodus.

4 Cf. Walter Brueggemann, Theology of the Old Testament: Testimony, Dispute, Advocacy (Minneapolis: Fortress Press, 1997), 226.

5 Cf. Gordon R. Clark, The Word hesed in the Hebrew Bible, JSOTSup 157 (Sheffield: JSOT Press, 1993), 179-180.

6 Terence C. Fretheim, Jeremiah, SHBC (Macon: Smyth \& Helwys Publishing, 2002), 460.

7 David M. Carr, “The Many Uses of Intertextuality in Biblical Studies: Actual and Potential," in Congress Volume: Helsinki 2010, ed. Martti Nissinen, VTSup 148 (Leiden: Brill, 2012), 531.

8 Cf. Benjamin D. Sommer, A Prophet Reads Scripture: Allusion in Isaiah 40-60 (Stanford: Stanford University Press, 1998), 8.

9 Cf. Sommer, Prophet, 11-15. Sommer applies Ben-Porat's approach to allusion. 
original use. ${ }^{10}$ The context of Jer 27:5, the source text of the quotation in 32:17, is that of YHWH announcing that he had given all the countries, who had sent envoys to Zedekiah, into the power of Nebuchadnezzar. By quoting 27:5 the author of 32:17 hints that YHWH was still in control.

There is a broad consensus that a relation of literary dependence exists between Jer 32:18a and the texts in the books of Exodus and Deuteronomy that display the so-called grace formula. The precise relationship is, however, disputed. Some scholars believe that Jer 32:18a alludes to Exod 34:6-7. ${ }^{11}$ Others are convinced that the author cites Exodus 20:5-6 and Deut 5:9-10. ${ }^{12}$ Lundbom even regards Jer 32:18a as a summary version of Exod 20:5-6; 34:7 and Deut $5: 9-10 .{ }^{13}$ In light of the lack of consensus with regard to the source text of the allusion in Jer 32:18a, it seems imperative to reconsider the evidence. The context of the source text as well as the manner in which the source text is utilised in Jeremiah might be meaningful.

\section{B THE SOURCE TEXT OF THE ALLUSION IN JEREMIAH 32:18A}

In Jer 32:18a as well as Exod 34:6-7 YHWH is characterised as the one who is merciful, but punishes sin. ${ }^{14}$ When one looks for verbal parallels, a more complex picture appears. In contrast to the extensive description of YHWH's positive attributes in Exod 34:6-7, Jer 32:18a limits the positive statement to the phrase עשה חסד לאלפים. Peculiar to Exod 34:7 is the use of the verb נצר. In Nah 1:2b נצר in in in all likelihood a pun on grace formula. ${ }^{15}$ The use of עשה in Jer 32:18a, however, can simply be attributed to a dependence on

10 Richard L. Schultz, The Search for Quotation: Verbal Parallels in the Prophets, JSOTSup 180 (Sheffield: Academic Press, 1999), 227.

11 Cf. for instance Walter Brueggemann, "A 'Characteristic' Reflection on What Comes Next (Jer 32:16-44)," in Prophets and Paradigms: Essays in Honor of Gene M. Tucker, ed. Stephen B. Read, JSOTSup 209 (Sheffield: Sheffield Academic Press, 1996), 21; Allen, Jeremiah, 368; Clark, Word, 179.

12 Andreas Michel, "Ist mit die Gnadenformel von Ex 34,6(+7?) der Schlüssel zu einer Theologie des Alten Testaments gefunden?" BN 118 (2003): 120; Fischer, "Gebete," 232 are of the opinion that the phrase עשה חסד לאלפים in Jer 32:18 recalls the Decalogue. Mastnjak, Deuteronomy, 161, believes that Jer 32:18 cites D's Decalogue.

13 Jack R. Lundbom, Jeremiah 21-36, AB 21B (New York, Doubleday, 2004), 512.

14 Denton has suggested that Jer 32:18 echoes Exod 34:6-7. Cf. Robert C. Denton, “The Literary Affinities of Ex XXXIV 6f," VT 13 (1963): 34.

15 Cf. Michael Fishbane, Biblical Interpretation in Ancient Israel (Oxford: Clarendon Press, 1984), 347; Gerlinde Baumann, Gottes Gewalt im Wandel: Traditionsgeschichtliche und intertextuelle Studien zu Nahum 1,2-8, WMANT 108 (Neukirchen-Vluyn: Neukirchener Verlag, 2005), 87-88. The author of Nah 1:2b was not necessarily acquainted with Exod 34:6-7, but could have responded to a stock credo regarding YHWH's character. 
either Exod 20:6 or Deut 5:10. ${ }^{16}$ Exodus 34:6-7 and Jer 32:18a also differ with regard to the verb used to describe the divine visitation. The verb פקד in the sense of to punish occurs frequently in the book of Jeremiah and is often used in a participial form with God as subject (cf. 11:22; 23:2; 29:32; 44:29; 46:25; 50:18). ${ }^{17}$ The author of Jer 32:18a, nevertheless, uses the verb שקד and not as in Exod 34:7 and the Decalogue texts. The verb שלם is also utilised in Deut 7:10, revealing a possible link with Jer 32:18a. Peculiar to Jer 32:18 is the use of the idiom שלם על חיק, "repays the sins into the bosom," an idiom which occurs elsewhere in the OT only in Isa 65:6, a text that is probably dependent on Jer 16:18. ${ }^{18}$ Curiously, the description of YHWH in Jer 32:19b as the one who rewards everyone according to his deeds, which seemingly attempts to correct v. 18a by introducing the concept of individual retribution, introduces the verb פקד into the prophet's prayer.

Although a reader might associate Jer 32:18a with Exod 34:6-7 on the basis of a shared motif, ${ }^{19}$ it does not necessarily imply that the author of the former text knew the latter text. It is rather a case of the authors of both texts applying the same stock credo regarding YHWH's character. ${ }^{20}$ Franz has noted that the text of inscription B from Khirbet Beit-Lei, which probably dates from

16 The use of the phrase נצר חסד, "keeping mercy," is unique to Exod 34:6. Van Seters argues that Exod 34:7 has modified the language borrowed from Deut 7:9 and 5:10 by using נצמר instead שמר, the common verb in Deuteronomy. Cf. John van Seters, The Life of Moses: The Yahwist as Historian in Exodus-Numbers (Louisville: Westminster / John Knox, 1994), 348-349.

17 Cf. Van Seters, Life of Moses, 348.

18 The idiom is also documented in Akkadian; ana sūni nadānu. Cf. Shalom M. Paul, Isaiah 40-66: Translation and Commentary, ECC (Grand Rapids: Eerdmans, 2012), 595-596.

19 A reader is likely to associate one text with another on the basis of shared motifs. That does not necessarily imply that the author knew the other text. Cf. Cynthia Edenburg, "Intertextuality, Literary Competence and the Question of Readership: Some Preliminary Observations," JSOT 35 (2010): 138 for a discussion with regard to the role of shared motifs.

20 Roy E. Garton, "Rattling the Bones of the Twelve: Wilderness Reflections in the Formation of the Book of the Twelve," in Perspectives on the Formation of the Book of the Twelve: Methodological Foundations - Redactional Processes - Historical Insights, ed. Rainer Albertz, James D. Nogalski and Jakob Wöhrle, BZAW 433 (Berlin: De Gruyter, 2012), 241, no. 11 has argued that it is likely that Joel 2:13; Jonah 3:9; 4:2; Mic 7:18; Nah 1:2-3 and Mal 1:9a are merely stock variants of a stock credo regarding YHWH's character rather than quotations of any singular text. According to Garton the grace formula does not appear to find its genesis in Exod 34:6-7, but rather in the cultic parlance of the broader Ancient Near East. 
587 BCE, or earlier, is terminologically closer to Exod 34:6-7 than any text in the OT. ${ }^{21}$

The correspondences between Jer 32:18a and Exod 20:6, Deut 5:10 and 7:9-10 call for a consideration of the relationship between Jer 32:18a and these texts. As was already noted, the phrase עשה חסד לאלפים occurs in Jer 32:18a as

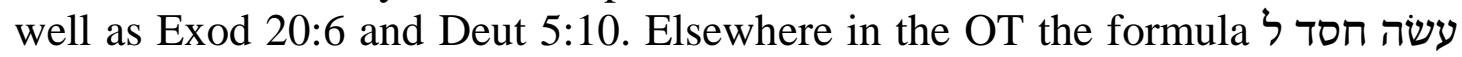
is only applied in 2 Sam 22:51 (par Ps 18:51[50]). Jeremiah 9:23, furthermore, attests to the use of the expression עשה חסד. Here it is asserted that YHWH directs his חסד to the inhabitants of the earth. ${ }^{22}$ The limited use of the phrase suggests that the correspondence between Jer 32:18a and the Decalogue texts should not be attributed to the use of stock vocabulary, but rather points to a literary dependence.

When one looks beyond the terminology being used, it is clear that Jer 32:18a is in several aspects closer to Exod 34:6-7 than to the Decalogue texts. In Jer 32:18 and Exod 34:6-7 the warning of divine visitation follows the statement regarding YHWH's forgiveness. The Decalogue texts have the opposite sequence, emphasising YHWH's justice. Jeremiah 32:18 agrees with Exod 34:6-7 by implying that YHWH's חסד is not dependent upon Israel's obedience. Both versions of the Decalogue stress that the people who will experience God's grace are those who love God and keep his commandments. Jeremiah 32:18a and Exod 32:6-7 both assert that YHWH will punish the children for the sins of the fathers. By the addition of לשנאי, "those that hate me," the Decalogue texts explicitly apply the announcement of punishment to the descendants that actively burden themselves with guilt. ${ }^{23}$ Another peculiarity of the Decalogue texts compared to Exod 34:6-7 and Jer 32:18a is the emphasis on YHWH as the אל קנה.

As was noted earlier, Jer 32:18a agrees with Deut 7:10 with regard to the use of the verb שלם. Deuteronomy 7:10 is also in agreement with Jer 32:18 and Exod 34:6-7 with regard to the sequence of YHWH's grace and the warning of divine visitation. However, in contrast to Deut 7:9-10, which asserts that

21 Matthias Franz, Der barmherzige und gnädige Gott: Die Gnadenrede vom Sinai (Exodus 34,6-7) und ihre Parallelen im Alten Testament und seiner Umwelt, BWANT 8/20 (Stuttgart: Kohlhammer, 2003), 97.

22 Cf. discussion in Clark, Word, 160.

23 Cf. Michel Konkel, Sünde und Vergebung: Eine Rekonstruktion der Redaktionsgeschichte der hinteren Sinaiperikope (Exodus 32-34) vor dem Hintergrund aktueler Pentateuchmodelle, FAT 58 (Tübingen: Mohr Siebeck, 2008), 179. Cf. also Moshe Weinfeld, Deuteronomy and the Deuteronomic School (Oxford: Claredon Press, 1972), 318; Cornelius Houtman, Exodus: Deel III, COut (Kampen: Kok, 1996), 37, 39. The characterisation of YHWH in Jer 32:19b as the one who rewards everyone according to his deeds is an attempt to introduce the concept of individual retribution into the prophet's prayer. 
YHWH requites the sinners instantly, Jer 32:18a discloses that he punishes the children for the sins of their fathers. This agrees with the sentiment of the survivors of the events of $587 \mathrm{BCE}$, as is expressed in Lam 5:7: "Our fathers have sinned, and are no more, and we have borne their iniquities."

The lengthy quotation in Jer 32:21-22 of Deut 26:8-9 implies that the author of Jer 32:16-25 was familiar with Deut 12-26. It is highly likely that he was also familiar with Deut 4:44-11:32. ${ }^{24}$ The narrative introduction in Jer 32:16 to the prophet's prayer, ואתפלל אל-יהוה, is a quotation from Deut 9:26. The description of YHWH in Jer 32:18b as the great and mighty God is dependent on Deut 10:17. ${ }^{25}$ It thus seems plausible that Deut 5:10 and 7:10 were known to the author of Jer 32:17-25. The author has, however, deliberately changed the order of YHWH's negative and positive attributes in Deut 5:10 attempting to emphasise YHWH's mercy. ${ }^{26}$ On the other hand, he chose to use the verb שלם, occurring in Deut 7:10, implying that the punishment had started. ${ }^{27}$ Since Deut 5 seems to be the literary home of the Decalogue, ${ }^{28}$ it is improbable that the author of Jer 32:17-25 responded to Exod 20:6.

${ }^{24}$ Parke-Taylor has demonstrated that except for Deut 20, 23 and 25 every chapter of the book of Deuteronomy has phrases found also in Jeremiah. Deuteronomy 4 and 28 present numerous parallels. Cf. Geoffry H. Parke-Taylor, The Formation of the Book of Jeremiah: Doublets and Recurring Phrases, SBLMS 51 (Atlanta: Society of Biblical Literature, 2000), 290.

25 Cf. also Neh 9:32. Deuteronomy 7:21 and 28:58 also emphasise YHWH's power.

26 One should approach the differences between a text and the text which is quoted with caution. As Nogalski has noted, an author may simply "quote" another text inexactly. An author may work from memory and simply record a slightly different version of the text. An author may deliberately alter the quotation to fit the context or to make a different point. Cf. James D. Nogalski, "Intertextuality and the Twelve," in Forming Prophetic Literature: Essays on Isaiah and the Twelve in Honor of John D. W. Watts, ed. James W. Watts and Paul R. House, JSOTSup 235 (Sheffield: Sheffield Academic Press, 1996), 104.

27 It is possible that the use of the verb שלם in Jer 16:18 was a contributing factor for its use in 32:18a. In Exod 34:7 the verb פקד seemingly suggests that YHWH will come to access the moral standing of successive generations before appropriate measures are taken. Cf. Michael Widmer, Moses, God and the Dynamics of Intercessory Prayer: A Study of Exodus 32-34 and Numbers 13-14, FAT 2/8 (Tübingen: Mohr Siebeck, 2004), 201.

28 Cf. Christoph Dohmen, "Decalogue," in The Book of Exodus: Composition, Reception and Interpretation, ed. Thomas B. Dozeman, Craig A. Evans and Joel N. Lohr, VTSup 164 (Leiden: Brill, 2014), 218; Konkel, Sünde und Vergebung, 267; Eckart Otto, "Der Dekalog als Brennspiegel israelitischer Rechtsgeschichte," in Alttestamentlicher Glaube und Biblische Theologie: Festschrift für Horst Dietrich Press zum 65. Geburtstag, ed. Jutta Hausmann and Hans-Jürgen Zobel (Stuttgart: Kohlhammer, 1992), 59. Dohmen aptly observes that the text of the Decalogue in Exod 20:1-17 stands outside the narrative surroundings. Cf. Dohmen, "Decalogue," 
To summarise: although Jer 32:18a is seemingly dependent of Deut 5:10 and 7:10, the author of the prophet's prayer made deliberate changes to the material which he borrowed. He did not only emphasise YHWH's mercy, but also attempted to signify that the punishment had started.

\section{THE EFFECT OF JEREMIAH 32:17-18A ON THE PROPHET'S PRAYER}

Following a narrative introduction in Jer 32:16, the prophet's prayer (vv. אדני יהוה אהה ("Ah, my Lord YHWH"). Surprisingly the complaint is followed by an affirmation of YHWH's power in creation. This has led to the view that vv. 17-23 with the exception of the invocation, did not belong to the original prayer. ${ }^{30}$ Verses 24-25 are however not a complaint, but a plea that YHWH should reassure Jeremiah of his intention to bring about normal life.

Jeremiah 32:17a $\beta-25$ falls into three parts: a lengthy doxology (vv. 17a $\beta$ -20) is succeeded by a description of YHWH's acts of benevolence towards Israel and the disobedient and ungrateful reaction of the people, which resulted in the calamity which YHWH brought upon them (vv. 21-23). ${ }^{31}$ The prophet's plea to YHWH at a time when Jerusalem was doomed to reassure him of his intention to bring about normal life concludes the prayer (vv. 24-25).

In the doxology references to YHWH's incomparable power alternate with statements recounting YHWH's conduct towards man. The doxology commences with the affirmation that YHWH is the creator of heaven and earth, for whom nothing is too difficult (v. 17). This is succeeded by the disclosure that YHWH shows mercy to thousands, but punishes the children for their fathers' sins (v. 18a). Next, YHWH is depicted as the great and powerful God, great in counsel and mighty in deed (vv. 18b-19a). This is followed by the statement that YHWH's eyes are open to the ways of all men, to reward everyone according to his deeds (v. 19b). ${ }^{32}$ The doxology concludes with the

192. According to Konkel the Decalogue was only taken up in the Sinai pericope when all the material was connected with the Priestly writings. Cf. Konkel, Sünde und Vergebung, 267.

29 Cf. Jer 1:6; 4:10; 14:13. It also occurs is Ezek 4:14; 9:8; 11:13; $21: 5$.

30 Cf. for instance Wilhelm Rudolph, Jeremia, HAT 1/12, 3rd ed. (Tübingen: J. C. B. Mohr [Paul Siebeck], 1968), 211; John Bright, Jeremiah, AB 21, 2nd ed. (New York: Doubleday, 1965), 294; Alexa F. Wilke, Gebete der Propheten: Anrufungen Gottes in "Corpus Propheticum" der Hebräische Bibel, BZAW 451 (Berlin: De Gruyter, 2014), 19.

31 In contrast to the preceding verses, finite verbs are used to describe the actions of YHWH and Israel in vv. 21-23.

32 Fishbane believes that the embarrassing reference to vicarious punishment in Jer 32:18a was countered by the statement in v. 19b that YHWH's greatness lies in the 
description of the deliverance from Egypt as a manifestation of YHWH's power (v. 20).

It is significant that in Num 14:17 Moses expresses the wish that YHWH's power (כח) should be displayed. Remarkably Moses does not ask YHWH to display his power in military terms, but in terms of covenant commitment (חסד). According to Moses patience, restraint of wrath and steadfast love is a sign of strength. ${ }^{33}$ In Jer 32:17 כח is explicitly related to YHWH's act of creating the heaven and the earth. The description of YHWH as the one "who shows steadfast love to thousands" does not express the hope that YHWH would show mercy to Israel by forgiving them. ${ }^{34}$ As was suggested earlier, the use of the verb שלם in 32:18a hints that the time of judgement has arrived. The prophet's prayer also lacks a plea for intervention. Jeremiah is not depicted as an intercessor on behalf of Israel, but as someone that struggles with the command to buy his nephew's field at a time when all seemed lost.

One would expect that the author of Jeremiah's prayer would link the disclosure that YHWH punishes the children for their fathers' sins (v. 18a) to a reference to him as the אל קנה in accordance with case in Deut 5:9-10. To the הגדול הגבור 10:17 by depicting YHWH as the In Deut 10:17 the description of YHWH as the great and mighty God substantiates the call to be obedient to God in the preceding verse. In Jer 32:18, however, the emphasis is evidently on YHWH's power. He is the one for whom nothing is too difficult.

The phrases גדל העצה ורב העליליה, "great in counsel and mighty in deed," occurring in Jer 32:19a, are unique to the OT. Holladay is of the opinion that Psalm 147:5, גדול אדונינו ורב־כח, might be a close parallel. ${ }^{36}$ Jeremiah 32:19a seemingly tempers the prophet's reproach in v. 25 that YHWH has directed him to buy his nephew's field.

The characterisation of YHWH in Jer 32:18a as the one who shows love to thousands, but brings punishment for the fathers' sins into the laps of the children after them, anticipates vv. 21-23. Verses 21-22 recall the exodus from

fact that he deals with each person according to his ways and according to the fruit of his actions. Cf. Fishbane, Biblical Interpretation, 342.

33 Cf. Widmer, Moses, 306.

34 Cf. for instance Jože Krašovec, Reward, Punishment and Forgiveness: The Thinking and Beliefs of Ancient Israel in the Light of Greek and Modern Views, VTSup 78 (Leiden: Brill, 1999), 127.

35 In the speeches that frame the book of Deuteronomy a series of statements characterize YHWH as the great, mighty and majestic God. Cf. Franz, Der barmherzige, 212221.

36 Cf. William L. Holladay, Jeremiah 2: A Commentary on the Book of the Prophet Jeremiah: Chapters 26-52, Hermen (Minneapolis: Fortress Press, 1989), 217. 
Egypt and the giving of the land, acts attesting to divine grace. The reference to these acts enhances Israel's history of ingratitude, gross enough to warrant the disaster which YHWH brought upon them (v. 23). ${ }^{37}$

Brueggemann has argued that the assertion in Jer 32:17 that nothing is too difficult for YHWH has the purpose of reminding him of his capacity to do something. ${ }^{38}$ Coupled with the statement that YHWH shows mercy to thousands YHWH is thus portrayed as the one who is expected to intervene. At a time when Judah was experiencing the power of the Babylonians, who conducted their campaign in the name of Marduk, the prophet testified to his belief in YHWH's incomparable power and disposition to intercede. The characterisation of YHWH as the one who punishes sin, could however not be disregarded. YHWH's threat to punish Judah's sins was brought to fruition. Jerusalem was surrounded by the Babylonians. ${ }^{39}$

\section{THE EFFECT OF JEREMIAH 32:17-18A ON YHWH'S RESPONSE TO THE PROPHET'S PRAYER}

The words of YHWH in Jer 32:26-44 are positioned to be a response to the prophet's prayer. ${ }^{40}$ Verse 17 and v. 27 have the use of the verb פלא in common. ${ }^{41}$ In v. 27 the expression אלהי כל־שר, unique in this form in the OT, does not merely recall the phrase ובישראל ובאדם in v. 20, but also the portrayal of YHWH as the creator of heaven and earth in v. 17. The citation in v. 36 is a paraphrase of v. $24 .{ }^{42}$

Interestingly vv. 28-29, which announce the deliverance of Jerusalem into the hands of the Babylonians, are connected to the rhetorical question in v. 27 by לכן. As was announced in 27:5, the source text of the quotation in 32:17, Jerusalem would be delivered by YHWH, the creator the earth into the power of the Babylonians in spite of them conducting their campaign against Jerusalem in the name of Marduk. Verses 30-35, introduced by the conjunction כ, provide the reason for YHWH delivering Judah into the hands of the Babylonians. Judah's history was one of disobedience towards YHWH (v. 31). The kings, the nobles, the priests, the prophets, all the people of Judah and the inhabitants of Jerusalem had turned their backs on YHWH (vv. 32-35).

37 Cf. Allen, Jeremiah, 369.

38 Walter Brueggemann, "Jeremiah: Creatio in Extremis," in God who Creates: Essays in Honor of W. Sibley Towner, ed. William P. Brown and S. Dean McBride (Grand Rapids: Eerdmans, 2000), 165.

39 Cf. Jer 32:24.

40 Cf. Brueggemann, "A 'Characteristic' Reflection," 24.

41 Cf. Brueggemann, “A 'Characteristic' Reflection,” 20.

42 Cf. Holladay, Jeremiah 2, 218. 
Verses 36-41, introduced by ועתה, express a shift from the present to the future. ${ }^{43}$ YHWH will bring the exiles back to Judah and conclude an eternal covenant with them. YHWH's future acts of salvation are thus contrasted with Israel's disobedience. While the motivation for bringing judgement can be traced to the people's sinful behaviour, the motivation for restoring his people lies solely within the realm of his own initiative. Interestingly the term אמת, a term occurring in the grace formula in Exod 34:6-7, is used to describe YHWH's act of returning Israel to their land in Jer 32:41. Unlike Jer 31:20-22, where the admission of guilt apparently motivates YHWH to return Israel from exile, ${ }^{44}$ repentance is not set in 32:36-41 as a precondition for restoration. One of the curses in Deut 28 is reversed in Jer 32:41 by the promise that YHWH will rejoice over his people for good. ${ }^{45}$ The characterisation of YHWH in 32:18 as the one who shows steadfast love to thousands would therefore be a fitting description of him as reflected by his acts announced in 32:36-41.

McKane cautions that the uniformity of style and vocabulary does not establish that Jer $32: 16-44$ is the work of a single redactor. ${ }^{46}$ For instance, 32:36-41 is frequently regarded as a later insertion. ${ }^{47}$ Rom-Shiloni, for example, attributes $32: 36-41$ to an author that did not belong to the Deuteronomistic editors. ${ }^{48}$ Stegeman has argued that while 32:43 addressed those living in Babylon, 32:36-41 was directed at a post-exilic group living in a situation of wider Diaspora. ${ }^{49}$ In spite of the fact that YHWH's reply to the prophet's prayer is multi-layered, ${ }^{50}$ the affirmation of YHWH's power and the characterization if him as the one who shows mercy to thousands, but punishes

43 Cf. Lundbom, Jeremia 21-36, 518.

44 Cf. Robert R. Wilson, "Poetry and Prose in the Book of Jeremiah," in Ki Baruch Hu: Ancient Near Eastern, Biblical and Judaic Studies in Honor of Baruch A. Levine, ed. Robert Chazan, William W. Hallo and Lawrence H. Schiffman (Winona Lake: Eisenbrauns, 1999), 424.

45 Cf. Mastnjak, Deuteronomy, 119-120. Cf. Deut 28:63a for the curse that YHwH would rejoice over Israel to destroy them.

46 William McKane, A Critical and Exegetical Commentary on Jeremiah: Volume 2: Jeremiah 26-52, ICC (London: Bloomsbury, 2014), 848.

47 Cf. for instance Siegmund Böhmer, Heimkehr und neuer Bund: Studien zu Jeremia 30-31, GTA 5 (Göttingen: Vandenhoeck \& Ruprecht, 1976), 43.

48 Dalit Rom-Shiloni, "The Prophecy for Everlasting Covenant (Jeremiah XXXII 3641): An Exilic Addition or Deuteronomistic Redaction?" VT 53 (2003): 223.

49 Janneke Stegeman, "'Reading Jeremiah Makes Me Angry': The Role of Jeremiah 32 [39]:36-41 in Transformation within the 'Jeremianic' Tradition," in Tradition and Innovation in Biblical Interpretation: Studies Presented to Professor Eep Taalstra on the Occasion of his Sixty-fifth Birthday, ed. Wido Th. van Peursen and Janet W. van Dyk (Leiden: Brill, 2011), 41.

50 The four messenger formulae in vv. 26, 27, 36 and 42 are perhaps signs of ongoing supplementation and expansion. Cf. Brueggemann, "A 'Characteristic' Reflection," 25. 
sins, evidently left its traces on the youngest layers. As is promised in 32:3641, YHWH will again intervene on behalf of his people. The great and powerful God will show steadfast love to thousands.

Fretheim has suggested that the implied answer to YHWH's question in Jer 32:27 whether anything is too difficult for him, is affirmative. ${ }^{51}$ Even if Fretheim is correct, it is evident that it was YHWH's incomparable power as is expressed in his acts as creator that would enable him to let the exiles return and start a new life in Benjamin and Judah (32:36-44). Because YHWH was the one who showed steadfast love to thousands, there would be a new future for the exiles in the land given to the ancestors.

\section{E CONCLUSION}

Jeremiah 32:17-18a attests to a peculiar use of the grace formula. It is linked to an affirmation of YHWH's incomparable power as is expressed by his acts as creator. The depiction of YHWH as the great and powerful God, who shows steadfast love to thousands, but punishes sins, serves as the guiding theme to Jeremiah's prayer (32:16-25) and YHWH's response to the prayer (32:26-44). In the prophet's prayer, set at a time when Judah was experiencing the power of the Babylonians, YHwH's incomparable power and his disposition to intercede, is highlighted. The characterisation of $\mathrm{YHWH}$ as the one who punishes sin, could however not be disregarded. Jerusalem was surrounded by the Babylonians.

In YHWH's response to the prophet's prayer, Jer 32:26-44, his incomparable power would enable him to cause the exiles to return and start a new life in Benjamin and Judah. The exiles were assured that new future would be realized because YHWH is the one who shows steadfast love to thousands.

Jeremiah $32: 16-23^{*}$ has rightly been described as a mosaic constructed from fixed expressions borrowed from other texts. The depiction of YHWH as the great and powerful God, who shows steadfast love to thousands, but punishes sins, does, however, make it a mosaic with a distinct pattern.

\section{BIBLIOGRAPHY}

Allen, Leslie C. Jeremiah: A Commentary. OTL. Louisville: Westminster John Knox, 2008.

Baumann, Gerlinde. Gottes Gewalt im Wandel: Traditionsgeschichtliche und intertextuelle Studien zu Nahum 1,2-8. WMANT 108. Neukirchen-Vluyn: Neukirchener Verlag, 2005.

Böhmer, Siegmund. Heimkehr und neuer Bund: Studien zu Jeremia 30-31. GTA 5. Göttingen: Vandenhoeck \& Ruprecht, 1976.

Bright, John. Jeremiah. AB 21. 2nd ed. New York: Doubleday, 1965.

51 Cf. Fretheim, Jeremiah, 464. 
Brueggemann, Walter. “A 'Characteristic' Reflection on What Comes Next (Jer

32:16-44)." Pages 16-32 in Prophets and Paradigms: Essays in Honor of Gene

M. Tucker. Edited by Stephen B. Read. JSOTSup 209. Sheffield: Sheffield

Academic Press, 1996.

. Theology of the Old Testament: Testimony, Dispute, Advocacy.

Minneapolis: Fortress Press, 1997.

. "Jeremiah: Creatio in Extremis." Pages 152-170 in God who Creates:

Essays in Honor of W. Sibley Towner. Edited by William P. Brown and S. Dean

McBride. Grand Rapids: Eerdmans, 2000.

Carr, David M. "The Many Uses of Intertextuality in Biblical Studies: Actual and

Potential." Pages 505-535 in Congress Volume: Helsinki 2010. Edited by Martti

Nissinen. VTSup 148. Leiden: Brill, 2012.

Clark, Gordon R. The Word hesed in the Hebrew Bible. JSOTSup 157. Sheffield:

JSOT Press, 1993.

Denton, Robert C. "The Literary Affinities of Ex XXXIV 6f." VT 13 (1963): 34-51.

Dohmen, Christoph. "Decalogue." Pages 193-219 in The Book of Exodus:

Composition, Reception and Interpretation. Edited by Thomas B. Dozeman,

Craig A. Evans and Joel N. Lohr. VTSup 164. Leiden: Brill, 2014.

Edenburg, Cynthia. "Intertextuality, Literary Competence and the Question of

Readership: Some Preliminary Observations." JSOT 35 (2010): 131-148.

Fischer, Georg. "Gebete als hermeneutischer Schlüssel zu biblischen Büchern - am

Beispiel Jeremia." Pages 219-237 in Congress Volume: Ljubljana 2007. Edited by André Lemaire. VTSup 133. Leiden: Brill, 2010.

Fishbane, Michael. Biblical Interpretation in Ancient Israel. Oxford: Clarendon Press, 1984.

Franz, Matthias. Der barmherzige und gnädige Gott: Die Gnadenrede vom Sinai (Exodus 34,6-7) und ihre Parallelen im Alten Testament und seiner Umwelt. BWANT 8/20. Stuttgart: Kohlhammer, 2003.

Fretheim, Terence C. Jeremiah. SHBC. Macon: Smyth \& Helwys Publishing, 2002.

Garton, Roy E. "Rattling the Bones of the Twelve: Wilderness Reflections in the

Formation of the Book of the Twelve." Pages 237-251 in Perspectives on the

Formation of the Book of the Twelve: Methodological Foundations -

Redactional Processes - Historical Insights. Edited by Rainer Albertz, James D.

Nogalski and Jakob Wöhrle. BZAW 433. Berlin: De Gruyter, 2012.

Holladay, William L. Jeremiah 2: A Commentary on the Book of the Prophet

Jeremiah: Chapters 26-52. Hermeneia. Minneapolis: Fortress Press, 1989.

Houtman, Cornelius. Exodus: Deel III. COut. Kampen: Kok, 1996.

Konkel, Michel. Sünde und Vergebung: Eine Rekonstruktion der

Redaktionsgeschichte der hinteren Sinaiperikope (Exodus 32-34) vor dem

Hintergrund aktueler Pentateuchmodelle. FAT 58. Tübingen: Mohr Siebeck.

2008.

Krašovec, Jože. Reward, Punishment and Forgiveness: The Thinking and Beliefs of Ancient Israel in the Light of Greek and Modern Views. VTSup 78. Leiden: Brill, 1999.

Lundbom, Jack. R. Jeremiah 21-36. AB 21B. New York: Doubleday, 2004.

McKane, William. A Critical and Exegetical Commentary on Jeremiah: Volume 2: Jeremiah 26-52. ICC. London: Bloomsbury, 2014. 
Mastnjak, Nathan. Deuteronomy and the Emergence of Textual Authority in Jeremiah. FAT 2/87. Tübingen: Mohr Siebeck, 2016.

Michel, Andreas. 'Ist mit der 'Gnadenformel' von Ex 34,6(+7?) der Schlüssel zu einer Theologie des Alten Testaments gefunden?" BN 118 (2003): 110-123.

Nogalski, James D. "Intertextuality and the Twelve." Pages 102-124 in Forming Prophetic Literature: Essays on Isaiah and the Twelve in Honor of John D. W. Watts. Edited by James W. Watts and Paul R. House. JSOTSup 235. Sheffield: Sheffield Academic Press, 1996.

Otto, Eckart. "Der Dekalog als Brennspiegel israelitischer Rechtsgeschichte.” Pages 59-68 in Alttestamentlicher Glaube und Biblische Theologie: Festschrift für Horst Dietrich Press zum 65. Geburtstag. Edited by Jutta Hausmann and HansJürgen Zobel. Stuttgart: Kohlhammer, 1992.

Parke-Taylor, Geoffry H. The Formation of the Book of Jeremiah: Doublets and Recurring Phrases. SBLMS 51. Atlanta: Society of Biblical Literature, 2000.

Paul, Shalom M. Isaiah 40-66: Translation and Commentary. ECC. Grand Rapids: Eerdmans, 2012.

Rom-Shiloni, Dalit. “The Prophecy for Everlasting Covenant (Jeremiah XXXII 3641): An Exilic Addition or Deuteronomistic Redaction?" VT 53 (2003): 200223.

Rudolph, Wilhelm. Jeremia. HAT 1/12. 3rd rev. ed. Tübingen: J.C.B. Mohr (Paul Siebeck), 1968.

Schultz, Richard L. The Search for Quotation: Verbal Parallels in the Prophets. JSOTSup 180. Sheffield: Academic Press, 1999.

Sommer, Benjamin D. A Prophet Reads Scripture: Allusion in Isaiah 40-60. Stanford: Stanford University Press, 1998.

Stegeman, Janneke. "“Reading Jeremiah Makes Me Angry': The Role of Jeremiah 32 [39]:36-41 in Transformation within the 'Jeremianic' Tradition." Pages 45-65 in Tradition and Innovation in Biblical Interpretation: Studies Presented to Professor Eep Taalstra on the Occasion of his Sixty-fifth Birthday. Edited by Wido Th. van Peursen and Janet W. van Dyk. Leiden: Brill, 2011.

Terblanche, Marius D. "Yahweh is the Creator of (Heaven and) Earth: The Significance of the Intertextual Link between Jeremiah 27:5 and 32:17." OTE 27 (2014): 637-650.

Van Seters, John. The Life of Moses: The Yahwist as Historian in Exodus-Numbers. Louisville: Westminster / John Knox, 1994.

Wanke, Gunther. "Jeremias Gebet nach dem Ackerkauf(Jer 32,16-25) und die Pentaeuch: Eine Problemanzeige." Pages 273-277 in Auf dem Weg zur Endgestalt vom Genesis bis II Regum: Festschrift Hans-Christoph Schmitt zum 65. Geburtstag. Edited by Martin Beck and Ulrike Schorn. BZAW 370. Berlin: De Gruyter, 2006.

Weinfeld, Moshe. Deuteronomy and the Deuteronomic School. Oxford: Claredon Press, 1972.

Widmer, Michael. Moses, God and the Dynamics of Intercessory Prayer: A Study of Exodus 32-34 and Numbers 13-14. FAT 2/8. Tübingen: Mohr Siebeck, 2004.

Wilke, Alexa F. Gebete der Propheten: Anrufungen Gottes in "Corpus Propheticum" der Hebräische Bibel. BZAW 451. Berlin: De Gruyter, 2014. 
164 Terblanche, “Jeremiah 32:17-18a,” OTE 30/1 (2017): 151-164

Wilson, Robert R. "Poetry and Prose in the Book of Jeremiah." Pages 413-427 in Ki Baruch Hu: Ancient Near Eastern, Biblical and Judaic Studies in Honor of Baruch A. Levine. Edited by Robert Chazan, William W. Hallo and Lawrence H. Schiffman. Winona Lake: Eisenbrauns, 1999.

Dr. Marius Daniel Terblanche is a research fellow at the Department of Old and New Testament Studies, University of the Free State, Bloemfontein. Email: mdterblanche@absamail.co.za. 